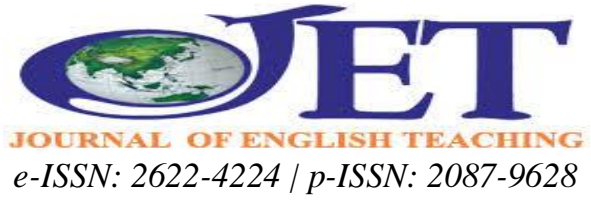

\title{
The Effectiveness of Short Story Use On Students' Speaking Skill Development at SMPN 160 Jakarta
}

\author{
Retta Mestika Ompusunggu \\ rettaops@gmail.com \\ English Education Deparment, Faculty of Teacher Training and Education, \\ Universitas Kristen Indonesia, Indonesia
}

\begin{abstract}
The use of short story as an essential component of second and foreign language teaching has recently been resurrected. Current studies also indicated that short story can facilitate effective learning of speaking. This study aimed at investigating whether short stories use was effective to develop students' speaking in English as a foreign language (EFL) context. To achieve the aim, a pretest-posttest experiment design using two groups of experimental $(n=30)$ and control $(n=30)$ was conducted at SMPN 160 Jakarta. The control group was taught speaking using short stories, while the control group was taught speaking in the routine procedure of the English classes. The experiment occurred in six weeks, two forty-five-minutes-sessions per week. Data was collected using tests administering the interview technique. The results of the hypothesis test employing SPSS22.00demonstrated that short story use had a significant effect on the participants' speaking skills improvement. It was, therefore, recommended to use short story to help students develop their speaking performance.
\end{abstract}

Keywords: EFL, short story, speaking skills

\section{INTRODUCTION}

Nowadays English has been "elected" the main lingua franca, or the common language consistently used as the main means of communication between people who do not share the same language. Although it is not the language with the highest number of speakers, it is a language that holds a dominant position and has far-reaching influence around the globe. It holds an official or semi-official status in over 60 countries around the world and 20 countries gave English a primary status. It is also used as the working language in $85 \%$ of international organizations (Crystal, 1997, p. 360). According to Graddol (1997), there are only 375 million people use English as a mother tongue. However, more than 375 million speakers use it a second language (ESL) and 750 million, as a foreign language (EFL). In addition, its use as the main gate to get a better job, especially in multinational companies have motivated a great number of people around the world to learn it as a second language or a foreign language in order to be able to speak in it.

Due to its preeminent rank in international communication, the mastery of English speaking skill has become increasingly important. Among the four language skills, speaking has even made the first priority to master. Richards and Renandya's (2002) asserted: "A large percentage of the world's language learners study English in order to develop proficiency in speaking" (p. 201). The tendency to prioritize the mastery of 
speaking is also reflected in the tendency of society to make speaking skills as a measure of one's mastery of English. Many students also consider language fluency to communicate verbally with others more important than the ability to read or write. They argue that speaking is the most important language skills that need to be controlled, and they assess learning achievement based on mastery of speaking skills (Burnkart, 1998). In line with this, Ur (1996) stated that “... of all the four skills (listening, speaking, reading and writing), speaking seems intuitively the most important: people who know the language are referred to as "speakers" of that language, as if speaking included all other kinds of knowing; and many if not most foreign language learners are primarily interested in learning to speak" (p. 120).

Despite the high importance of English speaking mastery, many EFL learners still find speaking "the most complex and difficult skill to master" (Hinkel, 2005, p. 485). According to Ur (1996), there are four main problems in getting students to speak in the foreign language in the classroom: inhibition, having nothing to say, low or uneven participation, and mother tongue use. The role of inhibition as a factor which causes speaking mastery difficult for students is verified by Bowman et al. (1989) who argued that when the teacher deals with speaking, he might ask his students to express themselves in front of their classmates which can lead to stressful and anxious situations while performing oral activities. In terms of the effect of mother tongue use, Baker and Westrup (2003) emphasized that "barriers to learning can occur if students knowingly or unknowingly transfer the cultural rules from their mother tongue to a foreign language" (p. 12).

Based on the present researcher personal observation, the students in SMPN 160 Jakarta also encountered those four barriers. Many of them seemed very fearful of making mistake and of being laughed by friends. Consequently, they tended to avoid to be involved in speaking practices. The students also did not get sufficient English exposures to be able to comprehend and respond effectively and efficiently. Moreover, the teacher explained the materials and gave the meaning of some words instructions mainly in Indonesian language.

To overcome these barriers, more effective learning and teaching strategies (Dakhi, 2014), activities, and environments that are interesting and motivating need to be facilitated. To accommodate that need, some scholars suggested using short story to facilitate effective learning of speaking. Ellis and Brewster (1991, pp. 1-2) stated that "as stories are motivating and fun, they can help students develop positive attitudes towards the foreign language and enrich their learning experiences". Similarly, Pardede (2011) argued, "Short story can also be a powerful and motivating source for teaching both speaking and listening. Oral reading, dramatization, improvisation, roleplaying, reenactment, and discussion are some effective learning activities which center on a short story EFL classes can be used for enhancing these two skills. Asking students to read story aloud can develop their speaking as well as listening skills. Moreover, it also leads to improving pronunciation" (p. 22). In addition, stories provide various topics for learners to begin a conversation with others (Deacon and Murphey, 2001, p.17).

Various current studies (e.g. Aliakbari \& Mohsennejad, 2014; Chalak, \&Hajian, 2013; Tien, 2013) have indicated the effectiveness of using short stories to develop EFL speaking skills. Pardede (2010) found that a majority of preservice English teachers at Christian University of Indonesia basically found short stories interesting to use both as materials for self-enjoyment and of as components language skill classes. 
The participants also approved the integration of short stories in language skills classes to help learners achieve better language skills mastery.

In relation to the description above, this study aimed at investigating the effect of using short story to students' speaking skill development at SMPN 160 Jakarta. It was conducted to answer the following question: "Is short story effective to develop students' speaking skill?"

\section{LITERATURE REVIEW Short-Story}

Short-story, which is defined as "... a narrative that can be read at one sitting of from one-half hour to two hours, and that is limited to 'a certain unique or single effect,' to which every detail is subordinate" (Abrams, 1970, p. 158), is viewed as the most suitable literature genre to use in public schools. The features of short story, i.e., it is relatively short, aims at giving a 'single effect', usually has one plot, involves a few characters; and excludes detailed description of setting make it is easy for the students to follow the storyline of the work. This idea is supported by the results of Hirvela and Boyle's (1988) study on adult Hong Kong Chinese students' attitudes towards four genres of literary texts (short story, novel, poetry, and drama). The results revealed short stories as the genre that is less feared since this genre is easy to finish and definite to understand. The idea is also in line with Collie and Slater (1991) who listed four advantages of using short stories: (1) short stories are practical as their length is long enough to cover entirely in one or two class sessions; (2) short stories are not complicated for students to work with on their own; (3) short stories have a variety of choice for different interests and tastes; and (4) short stories can be used with all levels (beginner to advance), all ages (young learners to adults) and all classes (morning, afternoon, or evening classes).

Using short stories in the EFL classroom exposes learners to distinctive opportunities for educational, intellectual, cultural and linguistic development. Short story is considered as one of the literary genres that can be used in the EFL classroom to enhance language skill, motivate students, and increase their cultural awareness and tolerance. Bouache (2010) argued that since the primary function of short stories is to entertain and inform, they keep interest alive in the classroom and motivate students, they have factual (real) and cultural values. They create a comfortable atmosphere and a good environment and enjoyable. King (2001) concludes that short stories can be utilized as engines, and a powerful and motivating source for assisting learners consolidate and practice language (grammar, diction). Similarly, Ellis and Brewster (1991: pp. 1-2) emphasize that "as stories are motivating and fun, they can help students develop positive attitudes towards the foreign language and enrich their learning experiences". The students who merely read the expository and documentary texts tend to sit passively on their seats, while the students who read short stories (which are motivating and interesting) will be driven to be more interested in classroom participation.

\section{Speaking}

Speaking is basically an interactive process of constructing and sharing meaning by using the oral language. Since it is interactive, it involves two people or more who are engaged in talking to each other (Harmer, 2007, p. 67) and produces and receive information by using oral language so that other people can make sense of them 
(Cameron,2001). Gebhard (1996) stated that "speaking is a process of building and sharing meaning through the use of verbal or oral form (p. 169). The form of speaking and meaning constructed depend on the context in which speaking occurs, including the participants themselves, their collective experiences, the physical environment, and the purposes for speaking. To successfully participate in speaking, a person needs to possess linguistic competence (including grammar, pronunciation, or vocabulary), and sociolinguistic competence (i.e., an understanding of when, why, and in what ways to produce language. Speaking is often spontaneous, open-ended, and evolving. However, speech is not always unpredictable.

Based on these concepts of speaking, three aspects could be identified: (1) speaking is face to face; (2) speaking is interactive; and (3) speaking happens in real time. Almost all conversations occur face to face which allows speakers to get immediate feedback. Therefore, speaking also involves nonverbal languages, such as facial expressions, gestures and even body movements. Speaking also occurs, most of the time, in situations where participants or interlocutors are present. Such factors facilitate communication (Burns, 1998; Widdowson, 1998). The aspect of interactive in speaking is seen in the fact that in every conversation the wheels of conversation usually turn smoothly, with participants offering contributions at appropriate moments, with no undue gaps or everyone talking over each other (Cornbleet\& Carter, 2001). Turn-taking, the main feature in interaction, is an unconscious part of normal conversation. Turn takings are handled and signaled differently across different cultures, thus causing possible communication difficulties in conversation between people of different cultures and languages (McDonough \& Mackey, 2000).

Speaking occurs in real time because during a conversation, responses are unplanned and spontaneous and the speakers think on their feet, producing language which reflects this (Foster et al., 2000: 368). These time constraints affect the speaker's ability to plan, to organize the message, and to control the language being used. Speakers often start to say something and change their mind midway; which is termed a false start. The speaker's sentences also cannot be as long or as complex as in writing. Similarly, speakers occasionally forget things they intended to say; or they may even forget what they have already said, and so they repeat themselves (Miller, 2001). This implies that the production of speech in real time imposes pressures, but also allows freedoms in terms of compensating for these difficulties. The use of formulaic expressions, hesitation devices, self-correction, rephrasing, and repetition can help speakers become more fluent and cope with real-time demands (Foster et al., 2000; Hughes, 2002: 76).

\section{Procedures of Teaching Speaking Using Short Story}

In speaking classes, short story is used by asking the students to retell it. This technique can make the students active in the classroom. There are some steps how to use retelling short story practice in teaching speaking. First, the teacher informs the students about the short story to be employed. Then the teacher asks the students to read the story, find and discuss difficult words. After that, the students practice how to pronounce unfamiliar words while the teacher walks around to observe and helps the students in either the pronunciation or the meaning. Then the students summarize the text. Fifth, the teacher asks the students to memorize the story. Finally, the teacher asks students to retell the short in front of the class. 
Pardede (2011) suggested the following activities teachers can assign to develop students speaking skills by using short stories. First, the students read the story aloud as a chain activity. For instance, the first student reads the first sentence. The second student takes the second sentence, the third student, third sentence, and so forth. Such activity will enhance students' pronunciation and fluency in an interesting way. Second, in an upper intermediate class, the students retell the story as a chain activity in small groups. Each student will have a lot of opportunities to practice the relevant connectors or other discourse markers in a meaningful context (They certainly should have been given a list of the connectors and discourse markers beforehand). Third, in an advanced class, the students are grouped into two groups. The first group is assigned to prepare arguments that support the major character's action or decision. Another group should prepare arguments to oppose the main character's action or decision. Fourth, the students are assigned to make a roleplay based on the story. This can be carried out by asking the students to play the role of several characters.

Various current studies have indicated the effectiveness of using short stories to develop EFL speaking skills. Aliakbari and Mohsennejad's (2014) study among 29 students of Zaban Sara Institute in Khorram Abad revealed that students speaking skill can be promoted by story retelling opinion gap. Tien's (2013) study revealed that the use of short story improved the students' speaking. Pardede's (2010) study revealed that a majority of the students of the English teachers training of Christian University of Indonesia basically found short stories interesting to use both as materials for selfenjoyment and of as components language skill classes. Most of them also agreed or strongly agreed that the incorporation of short stories in language skills classes will help learners achieve better mastery of language skills. Additionally, Storytelling also increases the accuracy of learners' speaking (Chalak \& Hajian, 2013). Gorjian, Moosavinia, and Shahramiri's (2011) study on the effects of telling oral summary of short story on 68 pre-intermediate Iranian male/female learners' speaking revealed that short-story retelling positively affected the students' speaking proficiency development.

Based on the discussion in previous sections, the hypotheses to test in this study were formulated as follow:

$\mathrm{H}_{\mathrm{o}}$ : There is no significant effect of using short story to develop students'speaking skill. $\mathrm{H}_{\mathrm{a}}$ : There is a significant effect of using short story to develop students' speaking skill.

\section{METHOD}

\section{Participants}

The Participants in this study were 60 eighthgradersofSMPN160Jakarta. A quasiexperimental design was used in this study. Due to administrative restriction, the sample was taken purposively by appointing the VIII-D class, consisting of 30 students, as the experimental group and the VIII-E class, consisting of 30 students, the control group. The experimental group learned speaking using short stories, while the control group learned in the routine procedure of their English classes. The experiment occurred in six weeks, two forty-five-minutes-sessions per week, from April to May 2018. 


\section{Materials and Procedure}

The materials and conditions used in this study were the same for both groups with the exception that the experimental group was assigned to learn using short stories while the control group learned in the routine procedure of their English classes, i.e. by using the passages provided in the main textbook of their English class. The short stories used in the experimental group were downloaded from many sources on the internet. The criteria used to select the story are: they are short (about 750-1500 words long), interesting to the students and written in the students' English level of mastery. The selected stories are Henry's The Gift of the Magi, Carver' Popular Mechanics, Hemingway's Old Man at the Bridge, The Legend of Malin Kundang, Bocaro'sA Long Walk Home, and Basho's The Aged Mother.

Each story was used in two sessions in the experimental class. In the first session, all students were assigned to read the story and find difficult words in pronunciation and meaning. After that, a discussion was conducted to determine the meaning of difficult words. Pronunciation practice was also conducted on unfamiliar words in a small group. During the practice, the teacher walks around to observe and helps the students. The students were then assigned to summarize the text. In the second session, five to six students were, in turn, asked to retell the short story in front of the class. A class discussion concerning the theme, character, and plot of the story was held at the end of the second session.

\section{Data Collection}

Data was collected using test technique, consisting of a pretest and a posttest. Both tests were carried out by interviewing each participant. The interview was recorded and assessed by two raters using a rubric adapted from Brown (2004, p. 172). The pre-test was administered to both of the experimental and control group before any treatment, whereas the post-test was administered after finishing the six weeks treatment. To analyze the data, the data, the descriptive statistic technique, and parametric statistical analysis by using SPSS version22.00 were employed.

\section{FINDING AND DISCUSSION}

\section{Data Description}

To assess the participants' initial speaking performance, the pretest was administered before conducting the experiment. The complete scores of the pre-test is presented in Table 1.

Table 1:

Statistic Description of the Control and Experimental Groups Pre-test Scores

\begin{tabular}{lllcl}
\hline Group & f & Mean & Minimum & Maximum \\
\hline Control & 30 & 38.50 & 34.00 & 47.00 \\
Experimental & 30 & 39.00 & 34.00 & 45.00 \\
$x$ & & 38.75 & 34.00 & 46.00 \\
\hline
\end{tabular}

Based on the pretest result, as shown by Table 1, the initial competence of both experimental and control groups was relatively the same. 
Table 2:

Pre-test and Post-Test Scores of the Control Group

\begin{tabular}{lllcc}
\hline Group & Scores & Mean & Minimum & Maximum \\
\hline Control & Pretest & 38.50 & 34.00 & 47.00 \\
& Posttest & 39.23 & 34.00 & 50.00 \\
& Gains & 0.73 & 0.00 & 3.00 \\
\hline
\end{tabular}

To see the effect of the teaching treatment in each group, a posttest was administered to both experimental and control groups. The comparison of the pretest and posttest scores of the control group are displayed in Table 2. The data revealed the group gained 0.73 points in terms of the mean score, and 3.00 score in terms of the maximum score.

Table 3:

Pre-test and Post-Test Score of the Experimental Group

\begin{tabular}{llrrr}
\hline Group & Scores & \multicolumn{1}{c}{ Mean } & Minimum & Maximum \\
\hline Experimental & Pretest & 39.00 & 34.00 & 45.00 \\
& Posttest & 44.40 & 35.00 & 55.00 \\
& Gains & 5.40 & 1.00 & 10.00 \\
\hline
\end{tabular}

As shown by the comparison of the pretest and posttest scores of the experimental group in Table 3, the group gained 5.40 points in terms of the mean score, 1.00 point in terms of the minimum score and 10.00 points in terms of the maximum score. Thus, the gains of the experimental group were higher than those of the control group in terms of means score, minimum score, and maximum score.

\section{Hypotheses Test}

The test hypothesis in this study, the paired test was employed. As stated previously, the hypotheses to test were formulated as follow:

$\mathrm{H}_{\mathrm{o}}$ : There is no effect of using short story to develop students' speakings kill.

$\mathrm{H}_{\mathrm{a}}$ : There is an effect of using short story to develop students' speaking skill.

The hypotheses statistic were:

$\mathrm{H}_{\mathrm{o}}$ is accepted if Sig. value $(\rho)>$ Sig. level $\alpha(0.05)$

$\mathrm{H}_{\mathrm{a}}$ is accepted if Sig. value $(\rho) \leq$ Sig. level $\alpha(0.05)$

The results of the hypothesis test were displayed in Table 4. As shown the table, the result of Sig (2-tailed) between pre-test and posttest was 0.000. This means that the $\mathrm{H}_{\mathrm{o}}$ was rejected and $\mathrm{H}_{\mathrm{a}}$ was accepted. In other words, the test revealed that short story was significantly and positively affected the eighth graders' speaking skill at SMP N 160 Jakarta. 
Table 4:

The Result of Independent Sample t-Test

Independent Samples Test

\begin{tabular}{|c|c|c|c|c|c|c|c|c|c|c|}
\hline & \multicolumn{5}{|c|}{ Levine's Test for Equality of Variances } & \multicolumn{3}{|c|}{$\begin{array}{l}\text { t-test for Equality of } \\
\text { Means }\end{array}$} & \multirow{2}{*}{\multicolumn{2}{|c|}{$\begin{array}{c}\text { 95\% Confidence } \\
\text { Interval of the } \\
\text { difference }\end{array}$}} \\
\hline & & & & & & \multirow[t]{2}{*}{$\begin{array}{l}\text { Sig. } \\
(2- \\
\text { tailed })\end{array}$} & \multirow[t]{2}{*}{$\begin{array}{c}\text { Mean } \\
\text { Difference }\end{array}$} & \multirow{2}{*}{$\begin{array}{c}\text { Std. } \\
\text { Error } \\
\text { Differenc } \\
\text { e } \\
\end{array}$} & & \\
\hline & & $\mathrm{F}$ & Sig. & $\mathrm{t}$ & df & & & & Lower & Upper \\
\hline Score & $\begin{array}{c}\text { Equal variances } \\
\text { assumed }\end{array}$ & .285 & .596 & -5.577 & 58 & .000 & -5.167 & .926 & -7.021 & -3.312 \\
\hline & $\begin{array}{l}\text { Equal variances } \\
\text { not assumed }\end{array}$ & & & -5.577 & 55.458 & .000 & -5.167 & .926 & -7.023 & -3.311 \\
\hline
\end{tabular}

The aim of this study was to find out whether or not there was asignificant effect of short story use on the eight graders' in speakingskillsatSMPN160Jakarta. Based on the mean scores obtained by the control and experimental group in both pretest and posttest as shown by Figure 1, the use of short stories obviously enabled the students in the experimental group achieved higher speaking performance than those in the control group who learned speaking without short stories, i.e. using in the routine procedure of their English classes. This is in line with Tien's (2013) finding that revealed the use of short story gave positive results to the students' speaking learning and improved their speaking skills.

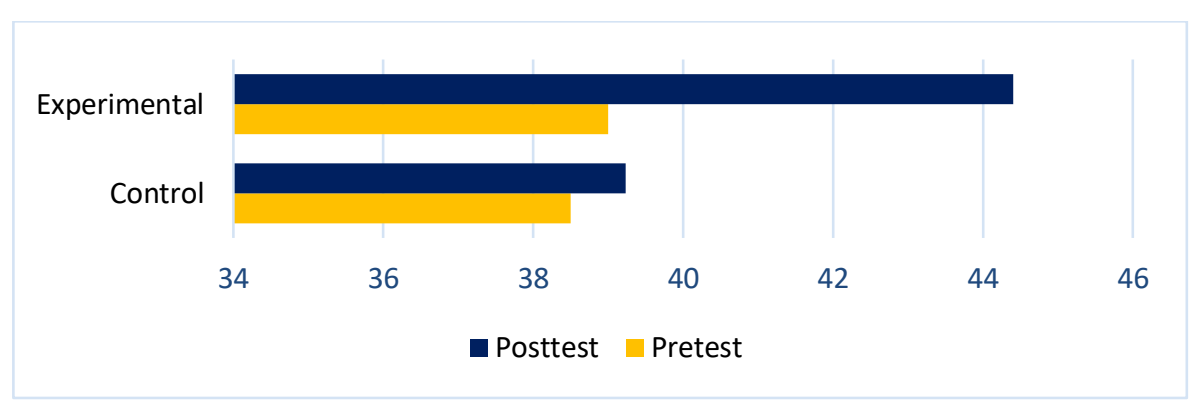

Figure 1: The Control and Experimental Group Pre-Test and Post-Test Mean Score

In addition, the results of the hypothesis test revealed that short story use significantly and positively affected the eighth graders' speaking skill at SMP N 160 Jakarta. This is in line with the results of Gorjian, Moosavinia, and Shahramiri (2011) studies revealing the positive effect of short-story retelling on developing speaking proficiency among 68 pre-intermediate learners. It also in line with the findings of Ebrahiminejadet. al. (2014)which indicated the students taught speaking using short story performed significantly better than the control group who learned speaking in the routine procedure.

\section{CONCLUSION AND SUGGESTION}

Based on the result obtained from this study it was found that students who attended the speaking class using short stories outperformed those who attended the class employing the routine procedure. Therefore, it can be observed that short stories are interesting to the students and their incorporation in speaking class can help learners achieve better 
mastery of speaking. This is closely related to the fact that that since the primary function of short stories is to entertain and inform, they keep interest alive in the classroom and motivate students, they have factual (real) and cultural values. In other words, short stories create a comfortable atmosphere and a good and enjoyable environment (Bouache, 2010). Therefore, students become more interested in classroom participation.

Due to some limitation of this study, three points are recommended. First, this study focused only on the effect of the use of short story on students' speaking performance. Consequently, attitudinal factors of the students were not identified. Thus, further studies are recommended to employ the mixed-methods design so that students' perceptions and interest could also be investigated. Second, the sample of this study could be selected randomly. As a consequence, there might be extraneous factors that affected the samples homogeneity. Therefore, further researches are recommended to employ random sampling technique to select the participants. Finally, the experiment in this study was conducted only in twelve sessions using six short stories. Conducting studies with a greater number of short stories in a longer period of time in the future might produce a more valid result.

\section{REFERENCES}

Abrams, M.H. (1970). A glossary of literary term. New York: Rinehart.

Aliakbari, M. \&Jamalvandi, B. (2010). The Impact of 'Role Play' on Fostering EFL Learners' Speaking ability; a Task-Based Approach. Journal of Pan-Pacific Association of Applied Linguistics, 14(1), 15-29

Baker and Westrup. (2000). The English language teachers' handbook. London: Continuum.

Bouache, R. (2010). The Impact of Listening to Short Stories on Comprehension. Unpublished Master's Thesis, Mentouri University, Constantine, Algeria.

Bowman, B., Burkart, G., \& Robson, B. (1989). TEFL/ TESL: Teaching English as a Second Language. USA: Centre of Applied Linguistics.

Brown, D. (2004). Language assessment: Principle and classroom practice. New York: San Francisco State University

Burnkart, G. S. (1998). Spoken language: What it is and how to teach it. Retrieved on April 26, 2010, from http://www.nclrc.org/ essentials/speaking/goalsspeak.htm.

Burns, A. (1998). Teaching Speaking. Annual Review of Applied Linguistics, 18(3), pp. 102-123.

Chalak, A., \&Hajian, S. (2013). The role of storytelling aloud on the accuracy of preintermediate Iranian EFL students' spoken language in the classroom. Journal of Faculty of Letters and Humanities, 8(28).

Cornbleet, S. and Carter, R. (2001). The language of speech and writing. London: Routledge

Crystal, D. (1997). English as a global Language (2 ${ }^{\text {nd }}$ ed.).Cambridge: Cambridge University Press.

Cameron, L. (2001). The teaching of speaking. Retrieved from: http://eprints.uny.ac.id/9933/3/CHAPTER\%202\%20-\%2006202244062.pdf

Collie, J.\& Slater, S. (1991). Teaching literature. Harlow: Longman.

Dakhi, S. (2014). Language learning strategy: A theoretical concept. Jurnal horison, Volume 2 (1). pp. 12-19. Retrieved from http://repository.uki.ac.id/261/ 
Deacon, B., \& Murphey, T. (2001). Deep Impact Storytelling. Forum, 39(4), Retrieve June 16, 2014, from http://exchanges.state.gov/forum/vols/vol39/no4/bio

Ebrahiminejad, S., et. al. (2014). Effect of Using Short Story on Speaking Improvement of Iranian Pre-Intermediate EFL Learners. International Journal of Language Learning and Applied Linguistics World (IJLLALW), 7(3), pp. 42-56.

Ellis, G., \& Brewster. (1991). The storytelling handbook for primary teacher. Middlesex: Penguin Group.

Foster, P., Tonkeyn, A. and Wigglesworth, G. (2000). Measuring Spoken Language: A Unit for all Reasons. Applied Linguistics, 21(3), pp. 354-375.

Gebhadrd, J. G. (1996). Teaching English as a foreign or second language. Ann Arbor, MI: University of Michigan Press.

Gorjian, B., Moosavinia, S. R., \&Shahramiri, P. (2011). Effects of Oral Summary of Short Stories on Male/Female Learner' Speaking Proficiency. The Iranian EFL Journal,4, pp. 34-66.

Graddol, D. (1997). The future of English? London: The British Council.

Harmer, J. (2007). The teaching of speaking. Retrieved from: http://eprints.uny.ac.id/9933/3/CHAPTER\%202\%20-\%2006202244062.pdf

Hinkel, E. (Ed.). 2005. Handbook of research in second language teaching and learning. New Jersey: Lawrence Erlbaum Associates, Inc

Hirvela, A., \& Boyle, J. (1988). Literature courses and student attitudes. ELT Journal, 42, pp. 179-184.

Hughes, R. (2002). Teaching and researching speaking. Warlow: Longman.

King, I. (2001): Beyond Cinderella: Using Stories with Secondary and Adult Learners. BETA- IATEFL. Language and Linguistic Studies, 4(2), pp. 94-106.

McDonough, K. \& Mackey, A. (2000). Communicative Tasks, Conversational Interaction and Linguistic Form: An Empirical study of Thai. Foreign Language Annals. 33(1), pp: 82-91.

Miller, L. (2001). A Speaking Lesson. How to Make the Course Book More Interesting. MET. 10(2), pp: 25-29.

Pardede, P. (2010). Short stories use in language skills classes: Students' interest and perception. In Proceedings of the 4th International Seminar. Bringing Linguistics and Literature into EFL Classrooms (pp. 1-17). Held in Salatiga, Indonesia, November 23-25, 2010, Satya Wacana Christian University.

Pardede, P. (2011): Using short stories to teach language skills. Journal of English Teaching, 1(1), pp. 14-27.

Richards, J.C. \&Renandya, W.A. (Eds). (2002). Methodology in language teaching. Cambridge University Press.

Tien, T. B. (2013). Using short stories to improve speaking skill at pre-intermediate level. Retrieved January 24, 2018, from https://123doc.org/document/3136407using-short-stories-to-improve- speaking-skill-of-students-at-preintermediatelevel.htm

Ur, P. (1996). A course in language teaching: Practice and theory. Cambridge: Cambridge University Press.

Widdowson, H. (1998). Skills, Abilities, and Contexts of Reality. Annual Review of Applied Linguistics, V. 18(3), pp: 323-33. 